\title{
UNAPREĐENJE EUROFIT BATERIJE MOTORIČKIH TESTOVA UPOTREBOM INFORMACIONE TEHNOLOGIJE
}

\author{
Vladan Marković*, \\ Aleksandar Živković, \\ Tamara Ratković, \\ Miloš Milošević
}

Univerzitet Singidunum, Beograd, Srbija

Odgovorno lice:

Vladan Marković

e-pošta:

vladanmarkovic@singidunum.ac.rs

\section{Rezime:}

Cilj ovog rada je bila analiza mogućnosti unapređenja Eurofit baterije motoričkih testova upotrebom informacione tehnologije radi postizanja bržeg, efikasnijeg i preciznijeg prikupljanja upotrebljivih podataka o motoričkom i funkcionalnom statusu dece predškolskog i školskog uzrasta. Predložena je upotreba revidirane baterije motoričkih testova i analizirana je mogućnost upotrebe softverskih i hardverskih (tehnološki unapređenih) rešenja u procesu merenja. Takođe je analiziran potencijal upotrebe revidirane baterije motoričkih testova u oblasti fizičkog vaspitanja i sporta. $\mathrm{Na}$ osnovu analiza zaključeno je da postoji potreba za konstrukcijom i validacijom predložene baterije testova što je preduslov njene široke praktične implementacije.

Ključne reči:

motoričke sposobnosti, merenje, digitalne tehnologije, fizičko vaspitanje.

\section{UVOD}

Razvoj digitalnih, pre svega informacionih i komunikacionih, tehnologija kao i prodor medija u privatni život ljudi, kroz njihovu povećanu prisutnost u svakodnevnom životu, ostavlja utisak neograničenog rasta njihovog uticaja u svim sferama ljudskog života i društva. Imajućí u vidu povezanost između tela i njegovih pokreta i kognicije, koje je u skladu sa evolutivnim stanovištem koje kao nužan uslov za pojavu svesti vidi kretanje [1], i Pijažeovim (Jean Piaget) stanovištem da inteligencija nastaje i razvija se iz ograničenog broja senzo-motornih (akcionih) šema [2, 3], odnos količine kretanja i konzumacije novomedijskih sadržaja posebno je problematičan. Iz ovog razloga je njihova negativna povezanost [4, 5], osnova kritike formativnog uticaja razvoja digitalnih tehnologija na mlade generacije.

Gojaznost i nepravilan fizički razvoj, kao posledica smanjenog kretanja uzrokovanog pre svega povećanjem vremena provedenog u gledanju televizijskog programa i igranju kompjuterskih igara i smanjenjem vremena provedenog u slobodnoj igri i aktivnostima u prirodi uočeni su još krajem prošloga veka. Ubrzani razvoj tehnologije, njena povećana dostupnost i masovna upotreba u sve ranijem uzrastu ostavljaju teške posledice pre svega po kognitivni ali i ukupan razvoj ličnosti. 
Broj dece kojima je dijagnostifikovan deficit pažnje i hiperaktivnost koji se manifestuju u formi ADHD (attention deficit hyperactivity disorder) sindroma ubrzano raste poslednjih godina i u Amerci obuhvata preko $11 \%$ predškolske i školske dece [6]. Broj dece sa sličnim simptomima koja nisu registrovana u zdravstvenom sistemu ili se u blažem obliku suočavaju sa ovim problemima značajno je veći. Iako je još uvek upitno šta je uzrok ovim promenama, on bi se mogao potražiti u trendu smanjenja fizičke aktivnosti i povećanja vremena koje deca provode ispred televizora, računara, mobilnog telefona i sličnih medijskih naprava [7]. Slično sugerišu i nalazi eksperimentalnih studija [8]. Mala je verovatnoća da će se uočeni trend povećanog prisustva medija u svakodnevnom životu promeniti, zbog čega se može očekivati nastavak rasta broja dece sa sličnim problemima u budućnosti.

Hiperaktivnost i nemogućnost usmeravanja pažnje imaju negativan uticaj na školsko učenje i postignuće [9], kao i funkcionisanje u socijalnim situacijama i povećanu agresivnost [10]. Bilo da se radi o dijagnostifikovanom sindromu ili blažem obliku poremećaja pažnje potreban je dodatni rad i stimulacija dece kako bi se izbegao loš razvojni uticaj. Iako studije pokazuju da fizička aktivnosti ima blagotvoran efekat kod dece sa ADHD sindromom $[11,12]$ i šire na razvoj pažnje i ostalih kognitivnih sposobnosti [13], detaljno ispitivanje povezanosti konkretnih kognitivnih i motoričkih sposobnosti tema je koja nije dovoljno dobro ispitana [14]. Zbog ovoga, iako se fizička aktivnost često od strane institucija, medija i prosvetnih radnika proklamuje kao efikasan način za menjanje negativnih bihejvioralnih manifestacija, pogotovo u školskom okruženju, lako se može uvideti nedostatak konkretizacije ovakvih preporuka, odnosno koji tip, vrsta, obim fizičke aktivnosti treba upražnjavati.

Jedan od razloga opisanih manjkavosti aktuelne istraživačke prakse treba tražiti u tradicionalnim metodama merenja motoričkih sposobnosti koje ne uspevaju da odgovore na potrebe radikalno promenjenog istraživačkog i društvenog konteksta. Eurofit baterija motoričkih testova jedan je od najilustrativnijih primera mernog instrumenta u širokoj primeni, kako u fizičkom vaspitanju tako i u sportu, čija su revizija i ponovna validacija neophodni kako bi se odgovorilo na opisane promene. U ovom smislu, nove tehnologije, zapravo treba da postanu saveznik u istraživanju i otklanjanju negativnih razvojnih posledica koje su paradoksalno njihovim razvojem i uzrokovane.
Cilj ovog rada je da analizira mogućnosti unapređenja Eurofit baterije motoričkih testova, upotrebom informacione tehnologije koja bi omogućila efikasnije, brže, obimnije i preciznije prikupljanje upotrebljivih podataka o motoričkom statusu pre svega dece predškolskog i školskog uzrasta što za krajnji cilj ima dolaženje do novih uvida i znanja u domenu fizičke kulture, sporta ali i kognitivnih nauka i psihologije što će pomoći kako istraživačima tako i praktičarima u preventivnom delovanju, stimulaciji pravilnog razvoja i otklanjanju negativnih razvojnih pojava.

\section{EUROFIT BATERIJA}

Testiranje motoričkih sposobnosti važan je element praćenja razvoja dece, bez obzira da li se bave sportom ili ne. Redovno testiranje dece omogućava praćenje razvoja onih sposobnosti koje su neophodne za pravilan razvoj, odnosno utvrđivanje da li i na koji način bavljenje sportom utiče na razvoj tih sposobnosti. Takođe, testiranje omogućava pravovremeno uočavanje eventualnih neuravnoteženosti u motoričkom razvoju, čime se olakšava rad na korekciji kao i kontinuirano praćenje dinamike napretka.

Savet Evrope je još 1963. godine kao jedan od svojih osnovnih ciljeva postavio omasovljenje upražnjavanja fizičke aktivnosti, kako u uzrastu predškolske i školske dece tako i u odraslom dobu, što je označeno kao „Filozofija: sport za sve“. Ovaj cilj proistekao je iz jasno uočene i opisane povezanosti fizičke aktivnosti i psiho-fizičkog razvoja i očuvanja zdravlja. U tu svrhu 1983. konstruisana je Eurofit baterija kardiorespiratornih i motoričkih testova koja je omogućila jeftino, lako i brzo prikupljanje podataka i praćenje fizičkog i zdravstvenog statusa predškolske i školske dece kao i razvojnih procesa.

U okvir Eurofit baterije ulaze sledeći testovi:

- Test ravnoteže - Flamingo Balance Test (FBL), ravnoteža,

- Taping rukom -Plate Tapping (PLT), frekvencija pokreta ruke,

- Duboki pretklon u sedu -Sit and Reach (SAR), gipkost,

- Skok u dalj iz mesta -Standing Borad Jump (SBJ), snaga mišića nogu,

- Dinamometrija šake - Hand Grip (HGR), jačina mišića šake,

- Ležanje-sed - Sit Ups (SUP), repetitivna snaga trupa, 
- Izdržaj u zgibu - Bent Arm Hang (BAH), mišićna izdržljivost ruku i ramenog pojasa,

- Čunasto trčanje - Shuttle Run 10x5 (SHR), brzina i agilnost $[15,16,17]$.

Eurofit baterija prošla je opsežne validacione studije [15] i zbog svojih karakteristika danas predstavlja zlatni standard u merenju i praćenju motoričkih sposobnosti dece predškolskog i školskog uzrasta, širom Evrope. Eurofit je i jedan od retkih instrumenata ove vrste koji je validiran i pogodan za primenu i kod dece sa posebnim potrebama ali i na starijim uzrastima [15, 17].

Sa druge strane, savremeno društvo i tehnološki napredak sporta prati i odgovarajuća moderna tehnologija testiranja. Sam podatak da je EUROFIT baterija testova dizajnirana pre punih 35 godina, govori da je ona u velikoj meri zastarela i prevaziđena, pre svega u izboru testova i opreme koja se koristi za sprovođenje istih.

Takođe, prediktivna moć rezultata dobijenih ovim testiranjem, pogotovo u cilju identifikacije talenata i selekcije vrhunskih sportista kreće se u opsegu od slabe do vrlo slabe u zavisnosti od konkretne sportske grane i sportske igre [17].

Osnovne metrijske karakteristike: valjanost, pouzdanost, osetljivost, i objektivnost standardizovanog procesa merenja Eurofit baterijom prilično su upitni za današnje standarde.

Čunasto trčanje $10 \times 5 \mathrm{~m}$ je test za procenu agilnosti, odnosno brzine promene pravca kretanja i kao takav, ne može se smatrati testom za procenu brzine. Ova konstatacija direktno utiče na valjanost primenjenog testa za procenu brzine, za koju je sprint na 20-30 m bio bolji izbor. Takođe, kod netrenirane populacije 10x5m je predugačak zadatak, odnosno završetak testa je pod uticajem mišićne izdržljivosti.

Dok valjanost direktno zavisi od izbora odgovarajućeg testa, preostale karakteristike su visoko zavisne od instrumenata koji se koriste za merenje. Na primer upotreba štoperice $u$ merenju vremena $u$ sprintu na nivou grupe daje slične rezultate kao i merenje foto-ćelijama, dok na bazi pojedinačnih rezultata ta greška značajno raste [18]. Sa druge strane, potencijalno još veće razlike se pojavljuju kada je objektivnost merenja u pitanju, pošto objektivnost direktno zavisi od merioca i njegovih sposobnosti (reakcija prilikom starta i prilikom prolaska kroz cilj). Na kraju korišćenje fotoćelija omogućava merenja sa prolaznim vremenima, dok bi štopericom bilo potrebno više merilaca (što dovodi do greške na svakom prolazu) ili posebna merenja za pojedine testove.
Sa druge strane, kod testa za procenu snage mišića nogu (skok u dalj iz mesta) problem je direktno u izboru testa, odnosno valjanosti testa skok u dalj iz mesta. Skok u dalj iz mesta zahteva viši nivo tehnike izvođenja u odnosu na vertikalni skok [19], pa samim tim vertikalni skok predstavlja logičan izbor, posebno kod populacije koja nije sportski usmerena. Takođe, postoji nekoliko metoda za procenu snage mišića nogu korišćenjem vertikalnih skokova od kojih se najčešće koristi metod merenja visine skoka na osnovu vertikalne razdaljine između inicijalne i finalne oznake nekog dela tela (prsti ruke, struk, glava, centar mase tela; Sardžentov skok, Abalakov skok) i metod merenja visine skoka na osnovu trajanja faze leta.

Po Sardžentovoj metodi ispitanik skače zamahujući rukama i pravi otisak kredom što je više moguće na zidu. Rezultat se izražava u maksimalnoj visini dohvata ili razdaljini između inicijalne i finalne oznake napravljene kredom - visini leta. Za ovaj protokol navodi se da predstavlja grubu procenu eksplozivne snage nogu [20]. S obzirom na to da se ovaj skok izvodi isključivo zamahom rukama, nalazi brojnih autora navode na zaključak da visina ovog skoka nije isključivo posledica snage ekstenzora nogu, što se mislilo da ovaj skok meri, već i koordinacije između zamaha ruku i ekstenzije u zglobovima nogu.

Abalakov (Вита́лий Миха́йлович Абала́ков) je prvi autor koji je razmatrao vertikalni pomeraj centra mase kao indikator postignute visine vertikalnog skoka. Po ovom metodu, ispitaniku se za specijalno dizajnirani pojas, smešten oko struka, zakači merna traka, koja je drugim krajem blago pričvršćena za kopču na podu, tako da se pri skoku može izvući. Visina skoka predstavlja razliku između mera koje pokazuje zategnuta traka pred skok i posle skoka. Na sličan način, pojedini autori merili su visinu skoka pomoću infracrvenih zraka emitovanih sa pojasa ispitanika na fotosenzitivne ćelije na zidu [21].

Prema ideji Abalakova da je indikator visine vertikalnog skoka vertikalno pomeranje centra mase tela, iskorišćen je napredak kompjuterske tehnologije da bi se procenjivala visina skokova na osnovu trajanja faze leta dobijene preko kontaktne podloge povezane sa modifikovanim tajmerom [22]. Metod merenja visine skoka na osnovu trajanja faze leta je moguć pomoću kontaktnih podloga (ili modifikacije kontaktnih podloga sa laserskim zracima) i platforme sile. Autori navode da visina skoka dobijena metodom merenja na osnovu trajanja faze leta nije u potpunosti precizna i da dobijene vrednosti prevazilaze stvarne vrednosti zato što je 
visina centra mase pri doskoku niža od one pri odskoku $[19,23]$. Do nepreciznosti merenja dolazi zbog različitih uglova u zglobovima kolena i skočnog zgloba pri odskoku i doskoku. Bez obzira na prethodne činjenice ova metoda je najjednostavnija i najprimenjivija u redovnim terenskim testiranjima sportista $[19,24]$.

$\mathrm{Na}$ kraju, problemi u pojedinim testovima ogledaju se pre svega u njihovoj osetljivosti, koja je takođe direktno povezana sa instrumentima koji se koriste. Tu se pre svega misli na test dinamometrije šake, koji se izvodi sa mehaničkim i elektronskim dinamometrima. Dok mehanički dinamometri daju samo rezultate produkovane sile na analognoj skali, elektronski pored produkovane sile mogu izmeriti i brzinu produkcije sile (rate of force development - RFD) [25, 26].

Pojedini važni indikatori motoričkog i funkcionalnog statusa kao što su brzina i agilnost ili mišićna izdržljivost nisu predmet direktnog i specifičnog merenja testova iz Eurofit baterije dok su u proces merenja takođe uključeni i ometajući faktori (interferišuće varijable). Tako je test izdržaj u zgibu pod velikim uticajem mase tela, pa se preporučuje upotreba testova pri kojima se dobija rezultat koji nije pod uticajem mase kao što su sklekovi, odnosno maksimalni broj sklekova koje pojedinac može da izvede.

Test ravnoteže, flamingo balans test, je test koji se izvodi na površini oslonca širine $3 \mathrm{~cm}$ pri čemu se administracija vrši brojem pokušaja za 60 sek. Moderna tehnologija omogućava nam primenu ovog testa, kao i drugih testova za procenu ravnoteže (npr. Roda test), korišćenjem elektronskih stabilometara, koji pored osnovnog rezultata u testu, može dati i čitav niz drugih podataka koji mogu imati ulogu u procenu zdravstvenog statusa pojedinca [27].

Tradicionalni način merenja manjkav je i u pogledu količine i upotrebljivosti odnosno pogodnosti za dalju upotrebu podataka koji se njima pribavljaju.

Sve nabrojane manjkavosti Eurofit baterije su zapravo kompromis koji je u njenom konstruisanju napravljen kako bi se obezbedila ekonomičnost (finansijska pre svega) i masovna upotreba. U promenjenom društvenom i tehnološkom kontekstu, ni zahtev za ekonomičnošću više se ne može smatrati kao ispunjen jer testiranja traju predugo. Sa druge strane, proces digitalizacije i demokratizacije tehnologije $[5,28]$ omogućio je znatno ekonomičnije merenje (i u vremenskom i u ekonomskom smislu) koje bi imalo bolje metrijske karakteristike. Takođe, podaci pribavljeni na ovaj način omogućili bi veću upotrebljivost ali i prediktivnu snagu testiranja.

\section{SOFTVERSKO REŠENJE}

Iako na tržištu postoji veći broj softverskih rešenja koja bi se mogla upotrebiti u svrhu prikupljanja podataka i njihove obrade, svako od njih vezano je za jedan ili nekoliko srodnih hardverskih sistema što zahteva kombinovanje više softverskih rešenja u sprovođenju testiranja većom baterijom testova.

Ovo je jedan od razloga zbog koga je potrebna konstrukcija novog softverskog rešenja koje bi omogućilo vezu i preuzimanje podataka iz svih opisanih hardvera odnosno povezivanje spoljašnjih uređaja sa centralnim računarom i očitavanje i dekodiranje informacija koje ulazni uređaj prikuplja. Ovako prikupljene informacije u drugom koraku iz raznorodnih mernih sistema na kojima se hardverska rešenja baziraju treba da budu u drugom koraku transformisana u jedinice SI sistema. Ovako kodirani podaci ređali bi se u numeričke matrice u predeterminisanom rasporedu, što bi omogućilo njihovu obradu i intrepretaciju na individualnom i grupnom nivou kao i poređenje između pojedinaca i grupa. Numerička matrica podataka koju bi kreirao softver tokom merenja trebala bi da bude kompatibilna najčešće korišćenim softverima za analizu i obradu podataka kao što su Metleb (Matlab), SPSS, Majkrosoft Eksel (Microsoft Excel) i slično.

Standardizovano softversko rešenje omogućilo bi umrežavanje i formiranje baze podataka. Pored praćenja i korišćenja u zaključivanju velikih globalnih uzoraka ispitanika, baza podataka obezbedila bi mogućnost praćenja napredovanja pojedinca i grupa i opisivanje individualnih i grupnih razvojnih procesa. Kombinovanje metode ponovljenog merenja i primene nelinearnih regresionih modela omogućilo bi procenu kapaciteta motoričkih sposobnosti [29], što je jedan od ključnih prediktora sportske uspešnosti [30]. Prednost koju umrežena baza podataka pruža je testiranje i korigovanje nelinearnih modela u realnom vremenu sa svakim novim izmerenim ispitanikom u bazi.

Pored prikupljanja podataka u svrhu naučnih istraživanja i praćenja stanja i razvojnih procesa pojedinca i populacije, u softversko rešenje bi trebalo integrisati i korisničku aplikaciju koja bi na osnovu prikupljenih podataka i izborom određenih predeterminisanih željenih efekata omogućilo planiranje i programiranje treninga kako na individualnom tako i na grupnom nivou (odeljenje, tim i slično). Praćenje efekata treninga predstavljalo bi i povratnu informaciju za korisnike koji se bave organizacijom fizičke aktivnosti (trenere i nastavnike fizičkog vaspitanja) o kvalitetu sprovedenih aktivnosti. 


\section{MOGUĆNOSTI PRIMENE U FIZIČKOM VASPITANJU I SPORTU}

Unapređena baterija motoričkih testova mogla bi se primenjivati u svim domenima u kojima se do sada primenjivao i Eurofit, s tom razlikom što bi omogućila validniji proces merenja i kvalitetniju upotrebu prikupljenih informacija.

Ovaj aspekt revidirane baterije motoričkih testova od posebne je važnosti za naučno-istraživački rad u oblasti nauka o fizičkom vaspitanju i sportu. Kvalitetnija istraživanja dalje će imati uticaj na podizanje kvaliteta pedagoške i sportske prakse.

Praćenje dinamike i kvaliteta psiho-fizičkog razvoja dece predškolskog i školskog uzrasta osnovni je cilj primene unapređene baterije testova $\mathrm{u}$ fizičkom vaspitanju. Iz žive interakcije prakse fizičkog vaspitanja i naučno-istraživačkog rada, koji ova baterija omogućava pre svega kroz upotrebu digitalnih informacionih i komunikacionih tehnologija, mogu se razviti kvalitetni programi za podsticanje psihofizičkog razvoja i prevenciju patoloških pojava. Pravovremena dijagnostika patoloških pojava omogućiće i pravovremeno reagovanje kroz kvalitetne interventne mere koje bi se takođe bile proizvod opisane interakcije teorije i prakse.

U domenu sporta, opisani proces merenja i praćenja razvojnih promena omogućio bi veću preciznost predikcije sportskih rezultata. Na ovoj mogućnosti zasniva se i potencijal upotrebe revidirane baterije u procesu identifikacije i selekcije talenata. Takođe, opisani proces prikupljanja i obrade podataka omogućio bi efikasnije planiranje, programiranje i praćenje efekata trenažnog procesa, kao preduslova za pravilan i efikasan razvoj talenata.

\section{ZAKLJUČAK}

Na osnovu sprovedenih analiza može se zaključiti da postoji potreba za unapređenjem (i revizijom) Eurofit baterije motoričkih testova. U ovom procesu postoji veliki prostor za upotrebu informacione tehnologije, koja bi donela unapređenje procesa merenja i povećala potencija upotrebe prikupljenih podataka.. Predložene inovacije i unapređenja Eurofit baterije imala bi svoju primenu u naučno-istraživačkom radu i praksi u fizičkom vaspitanju i sportu. Kao posebno važan aspekt njihove primene izdvaja se praćenje i podsticanje psihofizičkog razvoja dece predškolskog i školskog uzrasta, prevencija nepravilnog razvoja i intervencija kod pojave patoloških razvojnih procesa. $\mathrm{U}$ domenu sporta kao posebno važno mesto za primenu unapređene baterije motoričkih testova uočava se proces identifikacije talenata i selekcije, ali i sistematsko planiranje i programiranje trenažnog procesa i njegovih efekata.

Ograničenja šire primene informacionih tehnologija u modernizaciji Eurofit baterije u školskom kontekstu prevashodno se odnose na materijalna sredstva koja su potrebna pre svega za nabavku opreme i u manjoj meri za obuku kadra. Ipak, tend rapidnog opadanja cene i sa njim povezan proces demokratizacije tehnologije, kao i opisani benefiti njene primene u školskom kontekstu navode na zaključak da su dodatna materijalna ulaganja opravdana i isplativa.

Iz svega navedeno može se zaključiti da je opravdano krenuti u proces konstrukcije i validacije revidirane baterije motoričkih testova kao osnovni preduslov za njenu široku implementaciju.

\section{LITERATURA}

[1] L. Cosmides, and J. Tooby, Evolutionary Psychology: A Primer, Center for evolutionary psychology, 1997. http://www.cep.ucsb.edu/primer.html. Pristupljeno 01.03.2019.

[2] J. Piaget, Behavior and evolution, New York: Pantheon Books, 1978.

[3] J. Piaget, The Equilibration of Cognitive Structures: The Central Problem of Intellectual Development, Chicago: University of Chicago Press, 1985.

[4] A.Friedberg, The end of cinema: multi-media and technological change, in Gledhill, Christine; Williams, Linda (ed). Reinventing Film Studies. London: Arnold, 2000, pp 438-452.

[5] M. Milošević, Srpski film u doba novih medija (2010-2016), [Odbranjena doktorska disertacija]. Beograd: Fakultet dramskih umetnosti, 2019.

[6] S.N. Visser, M.L. Danielson, R.H. Bitsko, J.R. Holbrook, M.D. Kogan, R.M. Ghandour, R. Peroru, and S.J. Blumberg, Trends in the parent-report of health care provider-diagnosed and medicated attentiondeficit/hyperactivity disorder: United States, 20032011, Journal of the American Academy of Child and Adolescent Psychiatry, ,2014, 53(1):34-46. doi: 10.1016/j.jaac.2013.09.001.

[7] D.K. Eaton, L. Kann, S. Kinchen, S. Shanklin, K.H. Flint, J. Hawkins, W.A. Harris, R. Lowry, T. McManus, D. Chyen, L. Whittle, C. Lim, and H. Wechsler, Youth risk behavior surveillance - United States, 2011, MMWR Surveillance Summaries, 2012, 61(4):1-162. 
[8] L.E. Swing, A.D. Gentile, A.C. Anderson, and A.D. Walsh, Television and Video Game Exposure and the Development of Attention Problems. Pediatrics, 2010, 126(2): 214-221. doi: 10.1542/peds.2009-1508.

[9] T.D.S. Barry, R.D. Lyman, and L.G. Klinger, Academic underachievement and attention-deficit/ hyperactivity disorder: the negative impact of symptom severity on school performance, Journal of School Psychology, 2002, 40(3):259-283. doi: 10.1016/S0022-4405(02)00100-0.

[10] S. Mannuzza, R.G. Klein, H. Abikoff, J.L. Moulton, Significance of childhood conduct problems to later development of conduct disorder among children with ADHD: a prospective follow-up study, Journal of Abnormal Child Psychology, 2004 32(5):565-573.

[11] T.A. Hartanto, C.E. Krafft, A.M. Iosif, and J.B. Schweitzer, A trial-by-trial analysis reveals more intense physical activity is associated with better cognitive control performance in attention-deficit/hyperactivity disorder, Child Neuropsychol, 2016, 22(5):618626. doi: 10.1080/09297049.2015.1044511.

[12] C. Cornelius, L.A. Fedewa, and S. Ahn, The Effect of Physical Activity on Children With ADHD: A Quantitative Review of the Literature, Journal of Applied School Psychology, 2017, 33(2):136-170 doi: 10.1080/15377903.2016.1265622.

[13] K.. Lambourne, and P. Tomporowski, The effect of exercise-induced arousal on cognitive task performance: a meta-regression analysis, Brain Resrch. 2010, 1341:12-24. doi: 10.1016/j.brainres.2010.03.091.

[14] I.J. Gapin, D.J. Labban, and L.J, Etnier, The effects of physical activity on attention deficit hyperactivity disorder symptoms: The evidence, Preventive Medicine, 2011, 52:70-74. doi: 10.1016/j. ypmed.2011.01.022.

[15] C. Adam, V. Klissouras, M. Ravazzolo, W. Tuxworth, H.C.G Kemper, W. van Mechelen, H. Hlobil, G. Beunen, H. Levarlet-Joye, EUROFIT: European test of physical fitness. Rome: Council of Europe, Committee for the development of sport, CDSS, 1988.

[16] Annon, Testing physical fitness: EUROFIT. Experimental Battery Provisional Handbook. Strasbourg: Council of Europe, 1983.

[17] D. Drljačić, K. Arsić, D. Arsić, Primena Eurofit baterije testova u praćenju fizičkih sposobnosti i zdravstvenog statusa dece. PONS Medical Journal, 2012, 9 (4):158-164.

[18] R. Hetzler, C.D. Stickley, K.M. Lundquist, and I.F. Kimura, Reliability and Accuracy of Handheld Stopwatches Compared With Electronic Timing in Measuring Sprint Performance, Journal of Strength and Conditioning Research, 2008, 22(6):1969-1976. DOI: 10.1519/JSC.0b013e318185f36c
[19] H. Hatze, Validity and reliability of methods for testing vertical jumping performance, Journal of Applied Biomechanics, 1998, 14:127-140 .

[20] P. Balsom, Evaluation of physical performance, In: Handbook of Sports Medicine and Science: Football (Soccer) (ed. by B. Ekblom), Blackwell Scientific Publications, 1994, 102-123.

[21] A. Dal Monte, The functional evaluation of the athlete. Firenze, Sansoni, 2003,138-145.

[22] C. Bosco, P. Luhtanen, and P. Komi, A simple method for measurement of mechanical power in jumping, European Journal of Applied Physiology, 1983,50: 273-282

[23] A. Kibele, Possibilities and limitations in the biomechanical analysis of countermovement jumps: a methodological study, Jornal of Applied Biomechanics, 1998, 14: 105-117.

[24] N. Linthorne, Analysis of standing vertical jumps using a force platform, American Journal of Physics, 2001, 69(11): 1198-1204

[25] H.C. Roberts, H.J. Denison, H.J. Martin, H.P. Patel, H. Syddall, C. Cooper, and A.A. Sayer, A review of the measurement of grip strength in clinical and epidemiological studies: towards a standardised approach, Age Ageing 2011, 40 (4): 423-429.

[26] D. Allen, and F. Barnett, Reliability and validity of an electronic dynamometer for measuring grip strength. International Journal of Therapy and Rehabilitation, 2011, 18 (5): 258-264.

[27] A. Barabas, K. Bretz, and R.J. Kaske, Stabilometry of the Flamingo balance test. 14th International Symposium on Biomechanics in Sports. 1996, 162-165

[28] T. Friedman, The Lexus and the Olive Tree: Understanding Globalizatio, New York: Random House, 1999.

[29] M. Milosevic, and M. Milosevic, Model for assessing the physical status, as well as prediction and programming of training and sports performance of a soccer player, Journal of Physical Education and Sport, 2013, 13(4):479 - 488. DOI:10.7752/ jpes.2013.04076

[30] R. Tucker, M. Collins, What makes champions? A review of the relative contribution of genes and training to sporting success. $\mathrm{Br} \mathrm{J}$ Sports Med. 2012,46:555-561. doi:10.1136/bjsports-2011-090548. 